\title{
Cultura religiosa na Catagu(arte): apontamentos sobre a Festa de Santa Rita em Cataguases (MG)
}

Inácio Manoel Neves Frade da Cruz ${ }^{1}$ Universidade do Estado de Minas Gerais

Resumo: O objetivo deste artigo é analisar a mais tradicional festa católica ocorrida na cidade de Cataguases - MG. A proposta realça aspectos históricos entremeados com a observação etnográfica dos festejos em homenagem a Santa Rita de Cássia. Tal perspectiva ensejou o olhar em direção ao fluxo contínuo de interações entre os indivíduos envolvidos nas comemorações e tem como plano de fundo a ideia de vocação cultural associada à construção da identidade cataguasense.

Palavras-chave: Festa de Santa Rita, Cataguases, vocação cultural. 


\title{
Religious culture in Catagu(arte): notes about the feast of Santa Rita in Cataguases (MG)
}

\begin{abstract}
The goal of this article is to analyze the most traditional catholic feast happened in Cataguases's city - MG. The proposal enhance historic features intermingled with the ethnographic observation of the celebration in honour the Santa Rita de Cássia. Such perspective enabled the look toward the continuous flow of interactions between people involved in the celebrations and has as background the idea of cultural vocation associated with the construction of the cataguasense identity.
\end{abstract}

Keywords: Feast of Santa Rita, Cataguases, cultural vocation.

\section{Cultura religiosa en Catagu(arte): notas sobre la fiesta de Santa Rita en Cataguases (MG)}

\begin{abstract}
Resumen: El objetivo de este artículo es analizar la más tradicional fiesta católica ocurrida en la ciudad de Cataguases - MG. La propuesta realza aspectos históricos entremezclados con la observación etnográfica de los festejos en homenaje a Santa Rita de Casia. Tal perspectiva dio la mirada hacia el flujo continuo de interacciones entre los individuos implicados en las conmemoraciones y tiene como fondo la idea de vocación cultural asociada a la construcción de la identidad cataguasense.
\end{abstract}

Palabras-clave: Fiesta de Santa Rita, Cataguases, vocación cultural. 
I nicio com uma cena em movimento. Convido-os a imaginarem um homem correndo desesperadamente pelas ruas do centro da cidade e, em seguida, escalando a torre de uma igreja modernista na praça central da localidade. Um vigia do INPS gritando pega ladrão e o delinquente subindo, obstinadamente, pela estrutura de concreto. Na escalada, o sujeito se apoia apenas em cabos que ligam a haste de cobre do para-raios, do alto da cruz ao solo. Em suas costas, destaca-se a santificada imagem de Margherita Lotti, a Santa Rita. Em poucos minutos, esse fora da lei está livre de seus perseguidores. Alcançado o campanário, a quase quarenta metros do chão, mantém-se provisoriamente imune ao cerco da polícia. Sem aparentar a menor cerimônia, estabeleceu-se num dos signos religiosos mais consagrados: a cruz.

Desde a primeira hora da madrugada abraçado no para-raios, o transgressor viu o dia nascer sob um ângulo inusitado na modernista Cataguases, outrora município arquetípico do café 2 . Já ao romper da aurora, uma enorme quantidade de pessoas começou a se acotovelar para observar o homem agarrado no cume da torre. Como um animal acuado, só se encorajou a descer por volta das nove horas. Nenhum policial ousaria mirar e atirar em direção à cruz naquela beata povoação da década de 70. Para derrubá-lo dali, talvez, só um peteleco da Santa Rita. Mas, não havia sido pela sua própria mão que o bandido, como um dublê do HomemAranha, conseguira a proeza de alcançar o cume da torre? A excentricidade da paisagem imprimiu uma emoção violenta na multidão aglomerada na Praça Santa Rita. O Diário Oficial do Município estimou que cinco mil pessoas presenciaram a cena do homem sentado na cruz e, algumas horas depois, sendo conduzido à Delegacia de Polícia pelo "implacável" Sargento Cunha.

Tão logo retornou ao solo, o meliante disparou a rezar, não sem antes repetir insistentemente a pergunta: “Como eu fui lá em cima, meu Deus?” Entendido como uma novela, o fato foi assim narrado pelo repórter do mais tradicional jornal local: "Lá de cima ele contemplava uma multidão sedenta de versões sobre o acontecimento. [...] Foi um romance espetacular. Os fotógrafos se movimentavam [...]" (Jornal Cataguases, 28/04/1974). A atividade jornalística é encerrada com um ensinamento cristão, desde sempre ratificado como uma marca daquela comunidade. Preocupada não apenas com o castigo, mas, especialmente, com a salvação, a pedagógica mensagem recomendava que o dito cujo "procure estudar seu gesto e que tudo sirva de exemplo para salvá-lo. Ele, filho de Deus tem todo o direito de errar e Deus existe para isso: salvar as almas perdidas no tempo" (Jornal Cataguases, 28/04/1974). Neste episódio, não há dúvida de que o sagrado e o

\footnotetext{
${ }^{2} \mathrm{O}$ historiador norte-americano Peter Louis Blasenheim afirma que algumas cidades da Zona da Mata Mineira, tais como, Juiz de Fora, Leopoldina e Cataguases, têm sua história pontuada por um conjunto de elementos políticos e socioeconômicos que permitem designá-las como Municípios Arquetípicos do Café. Entre o final do século XIX e início do XX, a riqueza oriunda da produção e comércio cafeeiro ajudava a formatar uma sociedade acentuadamente desigual. Do ponto de vista cultural, essas localidades eram constituídas por uma elite ávida em investir parte de seu capital excedente em atividades artísticas que permitiam a recepção das novidades produzidas nas capitais.
} 
profano entreolharam-se. A opção por se refugiar no topo de um dos símbolos mais agudamente sagrados para os adeptos do catolicismo, não seria uma hierofania às avessas? Para uma cidade que se arvora em reduto vanguardista, mais pós-autônomo (CANCLINI, 2012), impossível.

Ao profanar um ícone sagrado, o outsider semianalfabeto poderia perfeitamente ser enredado, em suas reflexões, pelo grupo de intelectuais cataguasenses que, assim como seus congêneres, já naquela época distinguiam a mais alta virtude nas posturas que atacam crenças estabelecidas. Porém, alheio aos atos que permeiam o iconoclasmo, seu propósito não era destruir materialmente o símbolo religioso, muito menos contestar sua legitimidade. Entre o desespero em relação ao iminente encarceramento e a confiança na infalibilidade dos poderes divinos da Igreja, vislumbrou um esconderijo em um objeto de devoção. É provável que o fugitivo acreditasse mais na proteção do vigário do que em protagonizar uma cena em que a mão do homem anula a transcendência das divindades, contribuindo para suprimir a santidade das religiões (LATOUR, 2008). O evento do ladrão que após um furto malsucedido se escondeu/mostrou na cruz da Igreja Matriz, é uma das muitas histórias que se entretecem na Praça Santa Rita, em Cataguases. Esse é o lugar onde se desenvolve anualmente a mais badalada celebração religiosa da cidade.

Balizado pela fluidez das fronteiras entre o sagrado e profano, o propósito deste texto é analisar os processos de patrimonialização da Festa de Santa Rita, tendo como pano de fundo uma suposta crença dos cataguasenses nas narrativas que evocam uma espécie de mito da vocação cultural, legitimado por seu conjunto arquitetônico modernista, pelo cinema Maureano e pela literatura, através da Revista Verde3. A festividade religiosa em homenagem a Santa Rita de Cássia, ao polarizar moradores de todos os cantos e se assenhorear da parte central do espaço público, configura-se num campo capaz de ensejar reflexões sobre as relações de poder detectadas na conformação das tradições reinventadas e esquecidas. Párocos do santuário e freiras carmelitas, entre outras lideranças religiosas, representam uma parcela daqueles que disputam o direito de alçar a festa católica à condição de patrimônio imaterial de uma cidade dita vanguardista.

Como em praticamente todo o Brasil, os feriados das(os) padroeiras(os) mexem com o cotidiano e, ainda hoje, um bom naco da sociedade se faz representar nos festejos. Um dos traços distintivos desse tipo de atividade é o fato de congregar quase exclusivamente moradores da própria localidade, uma vez que a efeméride não coincide com nenhum feriado nacional. Em 22 de maio, apenas os habitantes de lugares em que a aludida personagem é patrona podem desfrutar de um descanso matizado com cores católicas. Sob os auspícios da folga, certas famílias optam por sair da cidade, muitas vezes tendo a zona rural ou a visita a casa de parentes como destino. Alguns indivíduos que possuem uma condição econômica um pouco mais abonada, preferem viajar, principalmente, para Juiz de Fora. Regra geral, perfazem um itinerário em que a visita ao Shopping Center costuma ser o carro-chefe do passeio. Corre a boca miúda a afirmação de que, no dia de Santa Rita, tropeça-se em cataguasenses nos estabelecimentos comerciais de Juiz de Fora.

3 Nome pelo qual ganhou certa notoriedade a corrente artística conduzida por um grupo de jovens escritores que, em 1927, fundou a Revista Verde, uma das primeiras manifestações literárias de cunho modernista produzida à margem dos circuitos metropolitanos. Alguns de seus principais integrantes: Enrique de Resende [1896-1973], Antônio Martins Mendes [1903-1980], Rosário Fusco [1910-1977], Ascânio Lopes [19o6-1929], Camilo Soares [1909-1982], Christophoro Fonte Boa [1906-1993], Francisco Inácio Peixoto [1909-1986], Guilhermino César [1908-1993] e Oswaldo Abritta [19081947]. Em 1978, a Metal Leve S. A. publicou uma edição fac símile dos números da Verde que circularam entre 1927 e 1929. 
Em suas considerações sobre a Escola de Chicago, Gilberto Velho afirma que os ajuntamentos urbanos formam um ambiente propício para uma imensa gama de trocas culturais. Segundo o antropólogo, a cidade pode ser compreendida como um laboratório para estudar a sociedade e "[...] não é à toa que Park está o tempo todo preocupado em mandar os seus discípulos e alunos para outros lugares, não só para as grandes cidades, mas também para as cidades pequenas e para o interior" (VELHO, 2005, p. 62). Sobre as solenidades comemorativas, compreendo os processos culturais que se conformam no ato das festas como fenômenos totais, ou seja, acontecimentos de categoria fisiológica, performativa, moral, estética, cosmológica e econômica (MAUSS, 2003). Neles, em alguns aspectos, pode-se notar que a dimensão inconsciente e não facilmente regulável da experiência humana possui o condão de atuar de modo marcante (CAVALCANTI; GONÇALVES, 2010, p. 260). Em razão da variante das formas e da diversidade dos seus meios de expressão, festejar o feriado da padroeira Santa Rita pode significar um desafogo para os populares e ao mesmo tempo expressar a história, valores, conflitos e dinâmica social dos grupos ali envolvidos (CAVALCANTI; GONÇALVES, 2010, p. 260).

As pesquisas sobre as comemorações constantes na agenda de cada localidade mostram que as festas são elementos invariáveis na vida individual e coletiva, em certos casos regulando-as no "ritmo de sua incessante sucessão no calendário" (PEREZ, 2012, p. 22). Em sua tese de doutoramento intitulada "Festa à brasileira" (1998), Rita Amaral evidencia no ato de festejar a linguagem simbólica através da qual poder-se-ia traduzir uma parcela dos valores nacionais. Nesse sentido, Cavalcanti e Gonçalves (2010, p. 259) alegam que as festas e o patrimônio constituem-se mediadores sensíveis entre passado, presente e futuro, tornando-se categorias fundamentais para o estudo dos fluxos de pessoas e ideias que reivindicam a festa como patrimônio cultural edificante da construção identitária de uma localidade ou de um determinado grupo.

Segundo a contagem informada pelos organizadores do evento, com a roupagem atual, a festa teve sua primeira versão no ano de 1978. Contudo, ao longo da história cataguasense a data vem sendo lembrada e ritualizada. Recordo que na primeira metade do século passado ganhava destaque a procissão que se apossava da quase totalidade do espaço público. Passo brevemente em revista uma das comemorações relatadas no Jornal Cataguases, de 23 de maio de 1929, informando que a venerada padroeira Santa Rita, realizara tradicionalmente "[...] a sua festinha [...] que constou de missa solemne com magníficos cantos, officiando os padres Cotta e Raul Coutinho, e tendo havido á tarde uma bem organisada procissão com o andor da padroeira cataguazense, abrilhantada com a 'Lyra Cataguazense"” (sic).

Meu olhar em direção à Festa de Santa Rita, uma comemoração dirigida às massas, vem ancorado no reconhecimento da capacidade do binômio arte e cultura de se impregnar na fisionomia da cidade. Caracterizada como uma terra de amantes das artes, umbilicalmente vinculada ao modernismo, em momentos pontuais, salientou-se como um espaço propício para manifestações culturais de vanguarda. Dois acontecimentos, ambos da década de 20, do século XX, fundamentam o mito da vocação cultural cataguasense: o Movimento Verde e a 
experiência cinematográfica com Humberto Mauro. ${ }^{4} \mathrm{Cem}$ anos após à criação dos marcos fundantes da sua história oficial, a cidade continua a abrigar indivíduos e instituições que se amparam nos fatos arrolados no mito para planejar e produzir festivais como o CINEPORT5 e o Festival de Ver e Fazer Filmes ${ }^{6}$. Ainda hoje, as construções formadoras da ideia de vocação cultural continuam a ser gerenciadas pelos discípulos de Rosário Fusco e Francisco Inácio, regra geral, contaminados por luminescências modernistas7. Imersos na confecção de seus textos e filmes e ocupados em manter ativas as reflexões a respeito das produções culturais de figuras associadas ao panteão cataguasense, seus intelectuais e artistas, em sua maior parte descolados do campo religioso local, quase nunca salientam as contribuições dos católicos para o conjunto patrimonial e tampouco parecem estar preocupados com a temática do estabelecimento da festa de Santa Rita como bem imaterial ou intangível, ou mesmo como mais um item do repertório artísticocultural cataguasense.

Todavia, se na esfera das manifestações artísticas o município salienta-se como sui generis, seu campo religioso não desabona o modelo padrão ratificado, em certo sentido, pelos exames desenvolvidos por sociólogos e cientistas da religião nos grandes centros. Numa palavra, está mergulhado num contexto permeado por uma maior visualidade dos sem religião, pela expansão galopante dos grupos pentecostal e neopentecostal (algumas vezes culminando num encolhimento das religiões afro-brasileiras) ${ }^{8}$, pela presença de religiões orientais, dos new agers, enfim, pela sensação de pluralidade potencializada pelo próprio recuo do catolicismo (SILVA, 2007; CAMURÇA, 2006; MARIZ, 2006; NOVAES, 2006; PIERUCCI, 2008). Como veremos adiante, o intento por parte dos católicos de tornar a festa de Santa Rita um marco obrigatório na agenda cultural cataguasense, faz parte da competição pelo domínio do campo religioso e pelo poder de opinar sobre quem e qual patrimônio merecem ser reverenciados. O relevo em alguns aspectos artísticos alinha o evento a uma memória impregnada de feitos culturais, aparentemente inverossímeis, atrelados ao universo local. Ao conceber estrategicamente a praça como um grande palco de contornos modernistas e a festa como um espaço cultural, os organizadores procuram acoplar algumas de suas ações às narrativas que atravessam a história e impelem a cidade em direção aos rituais artísticos.

\footnotetext{
4 Sobre os processos políticos e culturais que permeiam a construção de uma identidade cataguasense, conferir: a) OLIVEIRA, Marcos Vinícius Ferreira de. A ruína e a máscara: as contradições de uma modernização conservadora em Inferno Provisório, de Luiz Ruffato. 2011. 211 f. Tese (Doutorado em Letras) - Universidade Federal de Juiz de Fora, Juiz de Fora, 2011; b) XAVIER, Wescley Silva. O eterno legado modernista de Cataguases - MG no passadismo do círculo privilegiado da cultura. 2013. 300 f. Tese (Centro de Pós-Graduação e Pesquisas em Administração). Universidade Federal de Minas Gerais, Belo Horizonte, 2013; c) MELLO, Fernando Antonio Oliveira. Cataguases e suas modernidades. 2014. 354 f. Tese (Faculdade de Arquitetura e Urbanismo, UnB). Universidade de Brasília, Brasília, 2014.

5 Em 2005 foi criada uma confraria cinematográfica, que tem como principal propósito a execução do CINEPORT Festival de Cinema de Países de Língua Portuguesa. Tal evento logrou certa visibilidade e conta com o apoio de profissionais lusófonos com trabalhos reconhecidos em três continentes falantes da língua portuguesa: América, Europa e África. No ano de 2006, o ex-presidente da república portuguesa, Mário Soares, esteve em Cataguases prestigiando o CINEPORT. Por falta de apoio político, estrutura hoteleira e gastronômica, entre outros itens estruturais para esse tipo de evento, Cataguases "perdeu" para João Pessoa a oportunidade de sediar o festival no Brasil.

${ }^{6}$ Sobre o referido festival, conferir o link: http://www.festivalverefazerfilmes.org.br/2017/

7 Com importante contribuição na estrondosa maioria dos folhetos, folders, catálogos, suplementos literários, livros, opúsculos ou peças audiovisuais que versam sobre a cultura produzida por cataguasenses, ou em Cataguases, e na condição de epígonos dos mestres modernistas, podemos aqui citar os nomes de Joaquim Branco, Washington Magalhães, Ronaldo Werneck e Carlos Sérgio Bittencourt. A própria cunhagem da palavra Catagu(arte), presente no título deste artigo, deve ser creditada a Ronaldo Werneck, jornalista, poeta, estudioso e admirador de Humberto Mauro e Rosário Fusco.

8 Quanto à pertença religiosa, é importante registrar que segundo o projeto "Mapeamento das Religiões no Município de Cataguases", realizado entre 2010 e 2011, o percentual de participantes nas casas de religiões de matrizes afro-brasileiras era de 4,5\%, isto é, exageradamente superior aos 0,3\% informados pelo IBGE nos Censos de 2000 e 2010 . Ao final do mapeamento, identificamos e visitamos quarenta e duas casas umbandistas, sendo que em algumas delas o número de consulentes, médiuns e sacerdotes supera uma centena.
} 
Nestor Canclini (2008) sustenta a ideia de que o patrimônio serve para identificar um povo, entretanto, as assimetrias em sua constituição, apropriação e assimilação exigem compreendê-lo também como campo de luta material e simbólica entre as classes, as etnias e os grupos presentes numa dada sociedade. Aqueles que dominam, não possuem o controle de forma natural, podendo em alguns casos alinhar ideologias, projetos e famílias inteiras em posições conflitantes. O estudioso ensina que "consagram-se como superiores certos bairros, objetos e saberes porque foram gerados pelos grupos dominantes, ou porque estes contam com a informação e formação necessárias para compreendê-los e apreciálos, quer dizer, para controlá-los melhor" (CANCLINI, 2008, p. 195).

Em Cataguases, o processo de tombamento de bens imóveis, executado pelo IPHAN9, não ficou imune a certo controle e interferência de grupos locais, donos dos meios de produção e detentores de um elevado capital cultural. Sobre os valores atribuídos a cada bem no inventário das obras arquitetônicas, é importante não omitir a ressalva dos especialistas Paulo Alonso e Leonardo Castriota (2009), quando previnem a respeito do procedimento de tombamento viabilizado pelo IPHAN. Para eles, não foram produzidos, de fato, documentos justificando as normas apreciadas na escolha dos imóveis sugeridos para tombamento individual e, por conseguinte, não ficaram claros os critérios empregados na delimitação do centro histórico a ser preservado. Entre os projetos arquitetônicos desprezados para tombamento pelos especialistas do IPHAN, Castriota e Alonso salientam o da Matriz de Santa Rita, projetada por Edgar Guimarães do Valle.

Assim como o episódio do fugitivo na torre, uma das contendas sobre a igreja matriz respingou num encarte do jornal mais lido na cidade. É o caso de uma entrevista concedida por Francisco Inácio Peixoto, ao grupo ligado ao Movimento Literário Totem. ${ }^{10}$ Chico Peixoto tratou da construção da igreja como o elemento disparador da decadência de Cataguases. Em seu depoimento, alertava para a confusão entre "igreja moderna e modernoso". Não poupou nem o painel nem a artista Djanira, que na sua apreciação "não teve nem a honestidade de vir aqui para ver onde é que iam botar o painel dela". Que ocorresse um terremoto com epicentro na igreja e liquidasse aquilo, essa era a vontade de Peixoto, mecenas e principal mentor da aventura modernista de Cataguases, publicada no suplemento Totem, veiculado como encarte do Diário Oficial, em 05 de abril de 1979. Temos aqui um iconoclasmo em forma de praga, desta feita, pronunciado pela boca de um industrial, comunista e intelectual? Ressalvada toda a polissemia capaz de se agarrar à noção de patrimônio (GONÇALVES, 2009), é sempre interessante estar alerta ao fato de que é exatamente o patrimônio um dos terrenos "onde melhor sobrevive hoje a ideologia dos setores oligárquicos, quer dizer, o tradicionalismo substancialista" (CANCLINI, 2008, p. 160).

\section{O palco da festa: a Praça Santa Rita}

A Praça Santa Rita possui um lago, jardins, bancos de pastilha branca, piso em pedra portuguesa, árvores frondosas e é frequentemente habitada por pombos, canários, pardais, cachorros, camaleões, entre outros pequenos animais ${ }^{11}$. $\mathrm{O}$ retângulo que dá forma ao lago central possui um chafariz, geralmente ligado aos

\footnotetext{
9 Mais precisamente em 5 de dezembro de 1994, o IPHAN finalizava o processo de tombamento do centro histórico de Cataguases.

${ }^{10} \mathrm{O}$ grupo de literatura composto por jovens cataguasenses, adepto da poesia concreta, iniciou suas atividades em 1961, através do jornal O Muro.

${ }^{11}$ Nas décadas passadas, os bichos-preguiça faziam a alegria da criançada e dos adultos, sobretudo, quando desciam para as partes mais baixas das árvores. Hoje, eles não estão mais lá para serem observados.
} 
finais de semana, cujos jatos d'água conjugados com as luzes coloridas que dele emanam proporcionam aos visitantes o espetáculo das águas dançantes. Algumas vezes, esse tanque serve também para que um ou outro desajustado tome banho. Ao final das aulas, no colégio dirigido pelas freiras carmelitas, diversas crianças brincam em torno do lago e, não raro, alguma delas experimenta, involuntariamente, um banho em suas águas nada cristalinas. Para esses meninos e meninas, a praça pode ser compreendida como uma extensão lúdica da escola. Aos sábados, domingos e feriados, o tradicional sistema de sonorização alterna hits da música pop nacional e internacional.

Sua superfície é ladeada em quase toda a extensão por edificações pertencentes à Igreja Católica Apostólica Romana e ao Poder Público Municipal. Da parte do sagrado, o monumento com maior carga simbólica traz em sua fachada um painel em azulejos elaborado pela artista Djanira da Motta e Silva [19141979]. É quase consenso entre os admiradores das obras modernistas de Cataguases que o projeto arquitetônico da Matriz de Santa Rita ${ }^{12}$ sugere um avião com uma asa incompleta/quebrada. Ao lado direito da entrada da igreja, ocupando quase todo o quarteirão, localiza-se um prédio pertencente à ordem das irmãs Carmelitas, onde funciona um estabelecimento educacional: o Instituto Nossa Senhora do Carmo. Adiante, mais uma capela e, a seguir, o Educandário Dom Silvério, que abriga em seu interior um painel assinado por Emeric Marcier [19161990], intitulado "A criação do mundo"13. Aberto à visitação pública, encontra-se no educandário um memorial com obras de arte e objetos pertencentes à igreja católica. Em sua fachada, outra obra modernista insistentemente fotografada: o painel "Pássaros", de Anísio de Medeiros. No final da praça, situa-se o prédio destinado ao repouso das irmãs de caridade.

$\mathrm{Na}$ busca por seguir as pegadas deixadas pela estética moderna, com um estilo que remete ao fauvismo, a pintora cataguasense Nanzita quebrou a invariabilidade dos tons do interior da Matriz de Santa Rita, ao pintar, em 1995, em cores exuberantes "A via Crucis de Jesus Cristo". No outro extremo da praça, encontra-se a casa paroquial e mais uma edificação onde funcionam as atividades pastorais, o atendimento ao público e a organização da Diocese. Defronte à igreja principal, repousa o prédio onde está estabelecida a Prefeitura Municipal. Fruto de investimentos do capital excedente do café, a construção de dois pavimentos em estilo neoclássico oferece pistas para acessarmos diferentes temporalidades vividas naquele lugar de memória. Por fim, ao lado da Prefeitura, figura a Câmara Municipal no imóvel onde outrora funcionou o Banco do Brasil. Fora isso, um escritório de uma empresa de terraplanagem, uma dúzia de residências particulares e um prédio residencial de três andares. Concebida como um espaço público campeado por poderes da ordem do sagrado e do laico, fica inicialmente esboçada a moldura por onde reza, desfila e se diverte o povo cataguasense e, eventualmente, visitantes de outras paragens.

\section{A festa da padroeira Santa Rita de Cássia}

Nas últimas décadas, na semana antecedente ao feriado começam as atividades para a construção da quermesse que interdita e estrangula vias públicas e altera significativamente o cotidiano da porção central de Cataguases, além de

12 Edificada no espaço onde figurava o antigo templo neogótico, sua construção teve início em 1948 e foi concluída em 1968. O projeto para a Matriz de Santa Rita de Cássia, elaborado por Edgar Guimarães do Valle [1911-1968], foi parte integrante do rolo compressor modernista que reconfigurou esteticamente uma parte da porção central da cidade.

${ }^{13}$ Em Cataguases, na década de 50, Marcier também pintou o afresco "A lenda sobre o rapto de Helena de Tróia", na residência da artista plástica Nanzita Salgado. 
levar uma parcela de sua população a exercitar sua catolicidade. Os festejos ocorrem na praça onde foi erguida a Igreja Matriz, referência no mapa arquitetônico do modernismo mineiro. Diversos segmentos sociais estão implicados nas comemorações organizadas pelo Santuário Diocesano de Santa Rita de Cássia. A festa se estabelece com base na composição de um circuito de relações entre os colaboradores leigos da igreja, casais voluntários, grupos eclesiásticos e vários tipos de profissionais da cidade e região, com destaque para a música e o entretenimento. Tal rede se responsabiliza pelos agenciamentos dos recursos simbólicos e materiais, situando-se entre a esfera religiosa e a econômica.

Quando a festa se inicia, do interior das barracas da quermesse e nos tablados e palcos montados no santuário, padres, freiras e voluntários observam as pessoas - fiéis ou não do catolicismo - que passam ininterruptamente pelo local. Enquanto o consumo ou o estoque de seus produtos não cessam, continuam a monitorar os movimentos dos transeuntes, convidando a toda a gente para a compra de um bilhete de rifa aqui, de uma imagem ali, de um escapulário acolá. Em meio a esse exercício sutilmente panóptico, a maioria dos olhares e atenções se voltam para a barraca das comidas e bebidas, inclusive, alcoólicas, como a cerveja, leite de onça, batidas e licores. É a extensão em que trabalha um conjunto maior de voluntários e uma das principais fontes de renda do evento. No entorno desse barzinho gigante se reúnem personagens de praticamente todos os bairros, distritos e da porção central, propiciando um contato que envolve os mais diferentes tipos e aciona um leque bastante variado de assuntos. Afora o comércio oficial de bebidas, doces, salgados e petiscos, o espaço proporciona oportunidade para mais uma infinidade de ambulantes oferecerem desde as famosas caipi-frutas, passando pelos churros, maçãs do amor até os trabalhos de artistas plásticos, escultores, hippies e outros artesãos.

À exceção do carnaval e do desfile cívico do dia 7 de setembro, a festividade na qual a cidade consegue reunir mais almas é a que ritualiza a vida da sua padroeira. Na semana das comemorações, os organizadores da festa recebem milhares de pessoas para degustar o famoso Pastel da Santa Rita, saborear aquela cervejinha (vez ou outra) gelada, paquerar e manter em circulação os assuntos mais candentes do momento. Os acidentes automobilísticos e assaltos acontecidos nas redondezas, a roubalheira ou o descaso dos políticos locais, o futebol suburbano e o nacional, o amigo que ficou desempregado ou a conhecida que separou do marido, entre um rol nem sempre previsível de outros assuntos, são compartilhados em praça pública pelos frequentadores da festa.

A diversidade e [im]previsibilidade de encontros que se proporcionam naquele espaço permitem revirar algumas frações da história e da cultura local. Certas interlocuções ali estabelecidas possuem o condão de conectar uma imensa gama de significados simbólicos e alusões a ações específicas, constituindo a Praça Santa Rita num terreno onde se reproduz e circula uma memória atinente ao cotidiano dos quatro cantos do município, aí incluídos os distritos e zona rural. A área pública mantém o status de bem histórico e patrimonial, contudo, cada vez mais rubricada como extensão híbrida, pronta para continuar a se insurgir como ambiente propício para pôr em prática tanto a espiritualidade quanto os prazeres carnais. O referido espaço é central no processo de construção da memória coletiva, todavia, sua conformação dificilmente extrapola uma identidade única, "natural", teleológica, que acaba sempre e necessariamente desaguando no estuário cultural da cidade.

Além de conversar com organizadores e artistas participantes do evento, ano após ano, pude dialogar com uma razoável quantidade de personagens sem 
envolvimento direto com a festa. Muitos destes estavam ali para comer, beber e paquerar e não tiveram o menor constrangimento pelo fato de não assumirem uma pertença católica. Por outro lado, as camisas de uniforme estampadas com a imagem da Santa Rita ajudam a identificar aqueles que cooperam oficialmente com a festividade, em sua maioria, ávidos por declarar a satisfação por servir à instituição religiosa. Na contabilidade dos organizadores, o número de ajudantes, isto é, os que recebem o uniforme, nunca é menor do que quatrocentos e cinquenta voluntários. No diversificado grupo de participantes, para os mais devotos, se ocupar com os festejos pode demandar um tempo que extrapola a data reservada ao dia-santo, uma vez que o trabalho voluntário não começa nem termina em 22 de maio.

Das tardes pontuadas por orações e degustação, ao show pirotécnico da derradeira noite, a moldura arquitetônica em que coabitam obras modernistas com edificações de estilo eclético e neoclássico, oferece uma plasticidade especial às atividades. Naquela paisagem implacavelmente ambígua, as badaladas do sino convidam tanto para o consumo de cervejas, pastéis, caldos, bingos, flores, imagens, escapulários e medalhinhas quanto para as missas, ladainhas e procissão. Ao conversar com transeuntes na entrada e saída das missas, foi comum ouvir depoimentos, muitos deles clichês do tipo "este é um lugar em que me entrego a Deus" ou "estou aqui para recarregar a minha pilha da fé". A maior parte dos fiéis com quem travei contato admitiu "sair mais leve" das celebrações do dia 22 de maio. Com uma rosa em punho, as mulheres recriam na igreja uma passagem clássica na história de vida da padroeira: o florescimento, sob um rigoroso inverno, de rosas vermelhas e graúdas na horta por ela cuidada. Na perspectiva dos devotos da protetora, o contato mais íntimo com a santa pode contribuir para descarregar, sob a forma de pedidos e agradecimentos, as tensões e problemas do dia a dia, vertidos a partir da prática das orações e momentos de introspecção numa tentativa de religação com o santificado. Para uns, é chegada a hora de mentalizar/agradecer ao pé da santa e reconhecer a graça alcançada por um familiar. Para outros, o momento é de levar-lhe uma oferenda como prova de especial veneração e religiosidade. De festa em festa, os devotos de Santa Rita de Cássia renovam o ciclo do "pedir e esperar resignadamente pela graça".14

O feriado da padroeira configura-se um acontecimento capaz de embaraçar ainda mais os pequenos fios entrelaçados pelas perecíveis microssociedades (SIMMEL, 2009) que se formam no ambiente festivo. O viés performático agregado à experiência com o sagrado, faz com que certas diferenças entre os participantes da festa se tornem um pouco mais difusas. Em seus aspectos visuais, em certos momentos e de forma imprevista, ganha forma uma paisagem relativamente homogênea, visualmente composta por muitas mulheres e crianças trajadas com a indumentária representativa de Rita Lotti. A perspectiva mercadológica, com a atuação de agentes culturais e a indiscutível estratégia empresarial assentada na composição do evento, revelam uma série de agenciamentos consumados num jogo para o qual convergem os interesses em consolidar essa festa, concebida como um bem de raiz,${ }^{15}$ como uma tradição inventada (HOBSBAWM; RANGER, 1984), em mais um item do repertório que compõe o patrimônio cultural cataguasense.

14 Paula Montero (1999, p. 336) menciona as análises de Carlos Brandão como uma via de acesso para percebermos a lógica contratual implícita na reciprocidade ritual que compromete homens e santos a dar e receber.

${ }_{15} \mathrm{O}$ componente religioso esteve fortemente presente no projeto de ocupação da Zona da Mata Mineira. O surgimento da maior parte das cidades da região estava atrelado a uma espécie de pré-condição, isto é, à construção de um templo religioso Católico Apostólico Romano. 
A tradição que impele a enfeitarem a imagem da santa com rosas, figos e cachos de uvas, nomeadamente no dia 22, deriva dos relatos de que já no final de sua vida, durante um inverno rigoroso, foi encontrada na horta cuidada pela santa uma roseira repleta de belíssimas flores e uma figueira com frutos grandes e saborosos. As mulheres possuem o hábito de assistir as celebrações do dia 22 com uma flor vermelha nas mãos, revivendo o episódio da roseira em meio às intempéries. Dessa passagem de sua vida, ritualizada nas missas, deriva uma história exemplar que contribui para manter, em seus seguidores, acesa a chama da esperança em meio aos dissabores existenciais do tempo presente. O templo lotado, as rosas em punho e a atenção destinada às prédicas veiculadas pelos sacerdotes locais ajudam a traduzir o exercício de devoção católica praticado nas missas rezadas no dia da padroeira Santa Rita. No âmbito estético, o traçado da nave da igreja proporciona um enquadramento em que sugere efetivamente um sagrado moderno. Por outro lado, a rigor, da parte do nutricionismo, nada há de tão santificado na comilança. Entretanto, o ato de ingerir refrigerantes, álcool e frituras não aparenta ser um interdito ao bem-viver, posto que com a anuência dos padres e com a benção da santa. Como foi apresentado anteriormente, a quermesse reúne um contingente expressivo de voluntários e, ao que tudo indica, consegue auferir um volume considerável de capital em favor da igreja ao longo dos quatro dias de música, leilões, gastronomia, foguetório e o famoso Bingo da Motocicleta. Segundo a assessoria da diocese, os valores arrecadados são posteriormente revertidos em projetos sociais, reformas, manutenção e construção de Igrejas.

Sem perder de vista o recuo da dominação das instituições religiosas sobre a vida privada (DUBAR, 2009, p. 160), a solenidade alusiva à Santa Rita é prova inconteste de que o universo sagrado ainda atua como uma baliza significativa na ambiência da cidade. Naqueles dias de oração, recreação e comilança, a Igreja Católica volta a se apoderar, de forma contundente, do espaço público e protagoniza ações coletivas pautadas na interface entre espiritualidade e entretenimento. A estrutura da festa acaba por oferecer um aspecto majestoso em torno de algumas atividades ali reproduzidas. Lilia Moritz Schwarcz (2012, p. 317) destaca a capacidade dos monumentos arquitetônicos em ampliar as festividades e viceversa. Fato já salientado anteriormente, a solenidade de Santa Rita está contida num espaço que remete a uma espécie de monumentalidade imprescindível para os grandes festejos. O palco principal abarrotado de equipamentos de som, luz e vídeo, circundado por transeuntes de todos os tipos e idades, coloca a música na linha de frente do menu artístico atrelado à celebração religiosa. Contudo, uma plástica de inspiração católica pode ser percebida a partir das estátuas e quadros vendidos em barracas e também no vestuário das postulantes a Ritinhas.

Fazendo-se valer da grandiosidade do evento, a instituição eclesiástica procura chamar a atenção para o seu papel na mediação com o transcendental, na incessante busca por uma vida regulada por saúde, prosperidade e ética. Porém, em conformidade com o competitivo cenário de pluralismo religioso, não tem mais assegurada a exclusividade das ações, por vezes, sendo literalmente questionada e combatida em seu próprio território. Na tarde de 22 de maio de 2011, pude constatar a ação invasiva de um pequeno grupo de representantes da Igreja Universal do Reino de Deus/IURD. Uniformizados com suas tradicionais camisas com a estampa de um pássaro branco cravado num coração vermelho, nessa peleja, a tática adotada foi distribuir panfletos e jornais com a finalidade de orientar as pessoas sobre o "verdadeiro" caminho em direção a Deus, além de informar sobre os projetos assistencialistas desenvolvidos pela IURD. Diante desse tipo de situação, a festa pode ser compreendida sob mais de uma ótica, uma vez que se 
constitui numa fonte de legitimação das tradições, dos laços de solidariedade e do sentimento de pertença, mas também se transforma em arena para quizilas religiosas entre cristãos de diferentes roupagens.

A inclusão numa situação de festa religiosa, mesmo para quem não é fiel ardoroso daquela denominação, implica num contato direto com os componentes específicos da religião em questão. Nessas situações, o indivíduo geralmente se previne sobre o que agrada ou pode causar reação desfavorável em relação ao conjunto de princípios morais e éticos constituintes da crença ali compartilhada. As relações simbólicas entretecidas durante a festa, encontram-se atreladas não necessariamente a uma "[...] rede de regras que precisam ser seguidas, mas de regras que precisam ser levadas em consideração, seja como algo a ser seguido ou a ser evitado cautelosamente" (GOFFMAN, 2010, p. 53). É fundamental pensar nas muitas relações que se constroem com base no caráter polissêmico da festa. Por exemplo, enquanto para uma parcela dos participantes aquela reunião é uma ocasião propícia à ingestão de álcool e recreação, para outros pode ser a oportunidade de reviver um momento de labuta ao prestar o trabalho voluntário na montagem e desmanche das barracas e na limpeza do local. Na situação de festa, é comum percebermos no mesmo espaço posturas morais antagônicas, como as que colocam no espelho o decoro do trabalhador religioso diante da irreverência dos consumidores de bebidas alcóolicas.

Com os envolvidos diretamente na montagem dos palcos e barracas, o período de serviços pesados é bem maior do que as noites de ritmo quente nas diversas barracas, bingos, bilheterias e cozinhas. Alguns colaboradores só descansam um ou dois dias depois, quando finalmente conseguem desarmar, recolher e guardar toda a estrutura do evento. Nesse afazer espontâneo em nome da comunidade católica, um número significativo de aposentados retoma temporariamente o compromisso com o trabalho. Além de atender aos apelos das autoridades eclesiásticas, a mão de obra ali empregada coloca-se diretamente a serviço da santa. A possibilidade de contribuir para o êxito de uma atividade vinculada à esfera do sagrado é suficiente como justificativa para a maioria dos envolvidos tanto nas tarefas mais braçais quanto nas mais contemplativas.

Um dos pontos altos da festa é o bingo da tarde de 22 de maio, com o sorteio de motocicletas, computador e outros prêmios de menor envergadura. Certamente, no momento da aquisição, muitos escolhem os bilhetes com a intenção de contribuir para a religião que professam. Contudo, o ato sublime não exime outros santos católicos e tantas outras divindades de receberem pedidos para que o prêmio se encaminhe para o comprador. Infelizmente, pelo menos dessa vez, as graças perdem o âmbito da coletividade. Apenas o ganhador de cada objeto sorteado deverá agradecer penhoradamente à Santa Rita de Cássia e, quiçá, a outros protetores. No dia do bingo, das treze horas em diante, a praça fica repleta e o consumo de pastéis, refrigerantes e cerveja não perde de vista o ritmo alucinante da noite.

Integrando-se a uma composição ritualística pré-estabelecida, a festa também pode ser percebida como a culminância de uma sequência contínua de práticas litúrgicas, como as orações. No espaço público como no privado, a programação católica dá forma a uma agenda que encerra uma boa quantidade de datas reservadas ao culto religioso e ao preparo das atividades festivas. Em 13 de maio, por exemplo, tem início uma novena que só chega ao fim no dia 21, véspera do aniversário de morte de Rita Lotti. No dia 22 são rezadas missas às sete horas, oito horas e trinta minutos, quinze horas (batizada como a missa das Ritinhas) e dezoito horas e trinta minutos. Às dezessete horas ocorre uma procissão que 
percorre as ruas do centro da cidade e, por volta das dezoito horas e quinze minutos chega ao seu destino final, isto é, o Santuário. Entre uma missa e outra, os visitantes podem se divertir por conta das performances de bandas musicais, como é o caso de um dos grupos corais que fez relativo sucesso em 2013, cujo sugestivo nome "Katholik's", informa a pertença religiosa e aventa uma adesão à cultura americanizada.

Arte e religião não estão presentes apenas na música, nas pinturas de cunho modernista e no traçado curvilíneo dos prédios e monumentos religiosos. Para não perder de vista a semente que perpetua a fé e a devoção na padroeira, um bom número de meninas cobre o corpo com um hábito que remete à figura de Santa Rita de Cássia. As "Ritinhas", como são chamadas as crianças vestidas de santas, são impelidas a assistir às missas e participarem da procissão. A teatralização da festa é um dos recursos encontrados pela organização para conferir um relevo visual ao evento. Sublinhar o legado artístico produzido pela própria igreja é uma das maneiras como as lideranças sacerdotais de Cataguases manejam o elemento cultural e procuram reinventar uma série de práticas associadas, por vezes, a um sagrado que se permite experimentá-lo num ambiente de certa reflexividade. O monopólio religioso quebrado pela modernidade obrigou os católicos a saírem de uma zona de conforto e alterarem alguns expedientes na luta por sobrevivência. Na tentativa de continuidade (espiritual e econômica) e reforço das convicções cristãs junto ao seu rebanho, as lideranças locais acabaram por atualizar suas estratégias de sustento financeiro e aceitar alguns enlaces entre os modismos e a tradição, produzindo em Cataguases um acontecimento festivo com uma acentuada atenção nos componentes do lazer presentes nos dias de agito.

Do ponto de vista da dinâmica dos recursos financeiros, enquanto bares e lanchonetes sucumbem frente a um competidor fortíssimo, sobretudo na venda de cerveja e salgados, outros trabalhadores são claramente beneficiados. Nos dias que antecedem ao feriado, os comerciantes de rosas e flores em geral se regozijam com um acentuado incremento nas vendas. Satisfeito, o grupo de taxistas agradece. Butiques e os demais segmentos que trabalham com vestuário também têm motivo para comemorar. Pipoqueiros e outros ambulantes com presença assegurada na praça, estes então, vão ao delírio.

\section{Considerações finais}

Ao imprimir um olhar retrospectivo sobre a festa de Santa Rita, fica a sensação de que ano a ano o evento se robustece. Em suas últimas versões, apesar de não ser a única grande solenidade religiosa presente na agenda festiva do município, a performática quermesse atingiu um patamar de sedução de público para além das fileiras religiosas. Em nome de Santa Rita e, quase sempre, refletindo o apreço à catolicidade vivida por seus colaboradores, várias redes de solidariedade são reativadas ou intensificadas ao longo do mês de maio. A comemoração que combina devoção, missas, orações e procissão a quitutes, prêmios, performances artísticas, queima de fogos de artifício, paqueras, venda de objetos religiosos e bebedeiras, é mais um caminho para se manter viva uma certa identidade católica - sistematicamente alquebrada em virtude da fragmentação das agências estabelecidas no campo religioso - que ao acompanhar a marcha da globalização, lépida e vaporosa, se desmancha e reinventa continuamente.

Após atravessar quase toda a história local com status inabalável, no século XXI, as comemorações de Santa Rita não provocam mais consenso junto aos munícipes. A repercutida grandeza do evento também não garante a fidelidade do 
participante nos cultos e, muito menos, a adesão ao discurso religioso acionado pelos católicos. Se pensarmos no processo de laicização no sentido mais amplo, não podemos afirmar por quanto tempo terão energia para manter a imposição do calendário em relação ao descanso e à comemoração pública destinada à divindade patrona. As alegorias que mistificam a vocação cultural do município, ao se ocuparem em destacar os grandes feitos históricos, dão a entender que a arte é elemento que corre naturalmente nas veias de seu povo e brota viçosa em solo local. Quando contemplamos a praça e a encontramos teatralizada, repleta de Ritinhas, em certo sentido, estamos olhando para um espectro que se projeta todo o dia 22 de maio. Esse passado continua a incidir sobre o presente e, enquanto impele o diálogo entre arte e religião, mantém a festividade identificada com a vocação cataguasense.

No contexto configurado por um campo religioso desregulado, a perda da reserva de mercado por parte dos católicos permitiu a uma fração dos habitantes que tecessem uma visão mais reflexiva em relação aos elementos que permeiam, inclusive, as comemorações referentes ao período da quermesse. Uma parcela considerável da população ressalta o viés econômico em detrimento do sagrado, vocalizando uma crítica mordaz ao formato mercantilista do leque de recreações oferecido na festa. Na outra ponta desse gradiente crítico, encontra-se um pequeno grupo formado por intelectuais, artistas e outros atores sociais de maior capital cultural, cuja compreensão da espiritualidade vai ao encontro de um desenraizamento, uma desterritorialização dos assentamentos convencionais, enfim, uma condição alternativa à proposta cristã. Para eles, a festa de Santa Rita representaria literalmente um pouco daquele entulho religioso de viés cristãomonopolista que faltaria ser retirado do mapa para liberar o caminho em direção à abolição de qualquer tipo de reserva de mercado religioso, preservado aí o direito de não ter religião (PIERUCCI, 2006; 2008).

Um terceiro ponto de vista salienta que no modelo performático da celebração, o que se revela é um meio termo entre a obsessão pura e simples pela arrecadação de todos os tipos de donativos e capitais e uma ação desesperada para superar a condição de instituição que mais perde adeptos nos últimos anos. Em diversas etapas das comemorações, percebi suas lideranças escapulindo da previsibilidade e distanciamento dos sermões e buscado uma aproximação em relação aos cidadãos comuns. Tal estratégia alinha-se às leituras que apontam o caráter lúdico das festas como uma via alternativa para reprimir a sangria de fiéis, evidenciada nos últimos recenseamentos realizados pelo IBGE. A ênfase no divertimento possibilita ao evento penetrar numa dimensão profana, refletindo a sutileza dos jogos culturais detectada na relação com as tradições incorporadas ou repelidas por sua gente. Enredado no mito da vocação cultural, o movimento de patrimonialização da festa de Santa Rita, oferece um aspecto contemporâneo ao acontecimento, mas, ao mesmo tempo permite constatar que a localidade nunca conseguiu dissolver as tinturas de uma postura conservadora que delega a sua gente uma condição de obediência ao discurso religioso.

Os festejos terminam com a dissimulada obrigação de esgotar os estoques que resistiram aos primeiros dias. A última grande performance é a do show pirotécnico com cascatas de fogos descendo pelo painel da Djanira. Nesse grand finale, mais uma vez a obra de arte moderna de inspiração católica é o pano de fundo para onde convergirão os olhares da multidão espremida na praça. Durante os dez ou doze minutos de queima de fogos de artifício e estrondos, todas as atenções se voltam para a fachada com o painel de azulejos da modernista matriz. Por meio da pirotecnia, os agentes religiosos parecem acautelar: "confiem-nos suas 
almas, ainda nos sobrou algum poder". Após o último estampido, os pasteis voltam a ser devorados, as leitoas e outras prendas almejadas e, sem nenhum passe de mágica, a praça se abre novamente aos ritos profanos.

Recebido em 25 de maio de 2018.

Aprovado em 24 de setembro de 2018.

\section{Referências}

ALONSO, Paulo Henrique; CASTRIOTA, L. B. Conhecer para preservar: documentação e preservação do patrimônio modernista em Cataguases, Minas Gerais. In: $8^{\circ}$ SEMINÁRIO DOCOMOMO BRASIL. Cidade Moderna e Contemporânea: Síntese e Paradoxo das Artes, 2009, Rio de Janeiro. $8^{\circ}$ SEMINÁRIO DOCOMOMO BRASIL. Cidade Moderna e Contemporânea: Síntese e Paradoxo das Artes, 2009. v. 1.

AMARAL, Rita de Cássia de Mello Peixoto. Festa à brasileira: significados do festejar no país que não é sério. 1998. 387 f. Tese. USP, São Paulo, 1998.

BOURDIEU, Pierre. A economia das trocas simbólicas. São Paulo: Perspectiva, 2003.

. A distinção: crítica social do julgamento. São Paulo: Edusp, 2007.

CAMURÇA, Marcelo Ayres. A realidade das religiões no Brasil no Censo do IBGE2000. In: FAUSTINO, Teixeira; MENEZES, Renata (Orgs.). As religiões no Brasil: Continuidades e rupturas. Petrópolis: Vozes, 2006. (p. 35-48).

CANCLINI, Nestor Garcia. Culturas híbridas: estratégias para entrar e sair da modernidade. São Paulo: Edusp, 2006.

Imaginários culturais da cidade: conhecimento/espetáculo/desconhecimento. In: COELHO, Teixeira (Org.). A cultu ra pela cidade. São Paulo: Iluminuras, 2008. p. 15-31.

A Sociedade sem Relato: Antropologia e Estética da Iminência. São Paulo: EDUSP, 2012.

CAVALCANTI, Maria Laura Viveiros de Castro; GONÇALVES, José Reginaldo Santos. Cultura, festas e patrimônios. In: MARTINS, Carlos Benedito (coord.). Horizontes das ciências sociais no Brasil: antropologia. São Paulo: ANPOCS, 2010. p. 259-292.

DUBAR, Claude. A Crise das Identidades. A interpretação de uma mutação. São Paulo: EDUSP, 2009.

GOFFMAN, Erving. Comportamentos em lugares públicos. Rio de Janeiro: Vozes, 2010.

GONÇALVES, José Reginaldo Santos. O patrimônio como categoria de pensamento. In: ABREU, Regina; CHAGAS, Mário (orgs.). Memória e Patrimônio: ensaios contemporâneos. 2. ed. Rio de Janeiro: Lamparina, 2009. p. 25-33

HOBSBAWM, Eric; RANGER, Terence (Orgs.). A invenção das tradições. Rio de Janeiro: Paz e Terra, 1984. 
LATOUR, Bruno. O que é iconoclash? Ou, há um mundo além das guerras de imagem? Horizontes Antropológicos, Porto Alegre, ano 14, n. 29, p. 111-150, jan./jun. 2008.

MARIZ, Cecília Loreto. Catolicismo no Brasil contemporâneo: reavivamento e diversidade. In: TEIXEIRA, Faustino; MENEZES, Renata. As religiões no Brasil: continuidades e rupturas. Petrópolis: Vozes, 2006. (p. 53-68). (a referência abaixo estava colada nesta)

MARIZ, Cecília e MACHADO, Maria das Dores. Mudanças recentes no Campo Religioso Brasileiro. Mimeo, Rio de Janeiro, 1998.

MAUSS, Marcel. Sociologia e antropologia. São Paulo: Cosac Naify, 2003.

MONTERO, Paula. Religiões e dilemas da sociedade brasileira. In: BARROS, S. M. P. de (org.). O que ler na ciência social brasileira (1970-1995). v. 1. São Paulo: Anpocs: Capes, 1999. p. 327-367.

NORA, Pierre. Entre memória e história - a problemática dos lugares. Projeto História: Revista do Programa de Estudos Pós-Graduados em História e do Departamento de História da PUC-SP. São Paulo, n. 10, dez. 1993.

NOVAES, Regina. Os jovens, os ventos secularizantes e o espírito do tempo. In: TEIXEIRA, Faustino; MENEZES, Renata. As religiões no Brasil: continuidades e rupturas. Petrópolis: Vozes, 2006.

PEREZ, Léa Freitas. Festa, religião e cidade: corpo e alma do Brasil. Porto Alegre: Medianiz, 2011.

PEREZ, Léa Freitas; AMARAL, Leila; MESQUITA, Wania (orgs.). Festa como e em perspectiva. Rio de Janeiro: Garamond, 2012.

PIERUCCI, Antônio Flávio. Religião como solvente: uma aula. Novos Estudos CEBRAP. 2006, n.75, p. 111-127.

. De olho na modernidade religiosa. Tempo Social, São Paulo, v. 20, n. 2, nov. 2008, p. 9-16.

SCHWARCZ, Lilia Moritz. A aclamação é uma festa. In: PEREZ, Léa Freitas; AMARAL, Leila; MESQUITA, Wania (orgs.). Festa como e em perspectiva. Rio de Janeiro: Garamond, 2012. p. 314-335.

SIMMEL, Georg. Sociologia. São Paulo: Ática, 1983.

Religião: ensaios. São Paulo: Olho D’Água, 2009.

TEIXEIRA, Faustino; MENEZES, Renata. As religiões no Brasil: continuidades e rupturas. Petrópolis: Vozes, 2006.

VELHO, Gilberto. Reflexões sobre a Escola de Chicago. In: VALLADARES, Lícia do Prado (Org.). A Escola de Chicago. Impacto de uma tradição no Brasil e na França. Belo Horizonte: Editora UFMG, 2005. p. 53-68.

WAGNER, Roy. A invenção da cultura. São Paulo: CosacNaify, 2010. 